\title{
PERAN ETIKA DALAM MENINGKATKAN EFEKTIVITAS PELAKSANAAN PUBLIC RELATIONS
}

\author{
Susilawati Natawilaga \\ Fakultas Ilmu Komunikasi, Universitas Prof. Dr. Moestopo (Beragama), Jakarta \\ ss.natawilaga@gmail.com
}

Diajukan: 09-02-2018; Direview: 10-02-2018; Diterima: 30-06-2018;

\begin{abstract}
As one of the management functions of connecting various parties, public relations aims to foster internal and external relationships in shaping the common point of view and a positive attitude in the face of every condition, especially the crisis conditions, to build a positive corporate image and increase positive public support for the smooth implementation of the program and achievement of company goals. To fulfill its central role, public relation personnel must meet both tangible and intangible qualifications, especially in the form of ethical attitudes and behavior to cultivate or rehabilitate the negative public opinion that has arisen. Companies must also take proactive actions in the form of stress management, sensitivity analysis and predictive analysis to anticipate potential future crises, but still based on holistic and terintegrative strategies by maintaining and building public opinion through ethical and ethical behavior.
\end{abstract}

Keywords: Crisis condition, public opinion, ethical behavior dan proactive strategy

\begin{abstract}
Abstrak
Sebagai salah satu fungsi manajemen yaitu menghubungkan berbagai pihak, public relation bertujuan untuk membina hubungan internal dan eksternal dalam membentuk kesamaan sudut pandang dan sikap positif dalam menghadapi setiap kondisi, khususnya kondisi krisis, untuk membangun citra perusahaan positif dan meningkatkan dukungan publik positif terhadap kelancaran pelaksanaan program dan pencapaian tujuan perusahaan. Untuk memenuhi peran sentralnya, personil public relation harus memenuhi kualifikasi yang tangible maupun intangible, khususnya berupa sikap dan perilaku etis untuk menumbuhkan atau merehabilitasi opini publik negatif yang telah timbul. Perusahaan harus melaksanakan strategi proaktif berupa stress management, sensitivity analysis dan predictive analysis untuk mengantisipasi potensi krisis yang mungkin terjadi di masa mendatang, namun tetap dilandasi strategi holistic dan terintegratif dengan menjaga dan membangun opini publik melalui pemenuhan prinsip etika dan perilaku etis.
\end{abstract}

Kata Kunci: Kondisi krisis, opini pubik, perilaku etis dan strategi proaktif

\section{PENDAHULUAN}

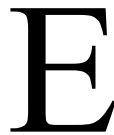
tika digunakan sebagai pedoman berperilaku dan diperluas menjadi etiket, merupakan suatu pedoman dan penentu individu maupun kelompok untuk bertidak sesuai kualifikasi keberadaban (civilization) dari masyarakat atau bangsa. Peran signifikan etika (etiket) semakin diperlukan saat pelaksanaan tugas public relation, dalam membinaan hubungan dengan para pihak yang memiliki kepentingan guna menciptakan corporate image positif, khususnya melalui pembentukan opini publik yang positif.
Adalah menjadi suatu pembelajaran yang komprehensif dan berharga atas peran etika dalam peningkatan peran public relation perusahaan dalam menghadapi kondisi krisis yang berpotensi menurunkan kredibilitas serta dukungan dari publik atas program yang dijalankan maupun positioning perusahaan dalam tatalaksana kehidupan berbisnis, bermasyarakat maupun bernegara.

Pada dasarnya etika merupakan standar nilai atau moral berkaitan dengan penilaian benarsalah dan atau baik-buruk. Tetapi walaupun etika dan moral memiliki makna yang kurang lebih 
sama, tetapi dalam kegiatan sehari-hari terdapat perbedaan dimana moral atau moralitas untuk menilai perbuatan yang dilakukan, sedangkan etika berkenaan dengan pengkajian sistem nilainilai yang berlaku.

Dalam kerangka konsep etika bisnis, khususnya berkaitan dengan hubungan sosial di antara perusahaan, karyawan dan lingkungannya, terdapat istilah etika perusahaan (corporate ethics), etika kerja (work ethics) dan etika perseorangan (personal ethics). Etika perusahaan berkaitan dengan hubungan di antara perusahaan dan karyawannya sebagai satu kesatuan dengan lingkungannya, misalnya perusahaan lain atau lingkungan masyarakat setempat. Etika kerja berkenaan dengan pengaturan tatakrama di antara perusahaan dengan karyawannya, sedangkan etika perseorangan berkaitan dengan hubungan di antara karyawan (employee relationship).

Agar Kode Etik Profesi dapat berfungsi secara optimal, harus diformulasikan oleh profesi terkait, sehingga akan dijiwai oleh cita-cita dan nilainilai yang hidup (living values), menjadi tumpuan harapan untuk dilaksanakan dan diupayakan secara tekun dan konsisten, serta menjadi hasil pengaturan diri (self regulation) dari profesi terkait. Walaupun tidak menutup bantuan dari pihak eksternal dalam penyusunan Kode Etik Profesi tersebut. Dan agar Kode Etik (Profesi) tersebut dapat berfungsi optimal, pelaksanaannya harus diawasi dan diperbaharui secara terus menerus (continuous improvement) sesuai dengan perkembangan bisnis maupun tuntutan global.

Tulisan ini akan membahas sejauhmana kepatuhan perusahaan, khususnya public relation, terhadap Kode Etik Public relation maupun etika sebagai Professional Public relation di dalam perusahaan dalam menangani kondisi krisis, yaitu suatu keadaat darurat yang terjadi secara tiba-tiba, dan bersifat tidak stabil, bergerak ke arah suatu titik balik dan menyandang potensi perubahan yang menentukan. Krisis tersebut dapat didefinisikan dalam tiga elemen yang paling umum, yaitu ancaman bagi organisasi, unsur kejutan dan keputusan waktu yang singkat.

Adalah menjadi tugas utama bagi public relation untuk mengkomunikasikan keadaan sebenarnya dari kondisi krisis dan penanganan yang teah dan akan dilaksanakan. Komunikasi merupakan proses penyampaian infromasi (dalam bentuk pesan, ide atau gagasan), dari satu pihak kepada pihak lain, untuk merubah pandangan, gagasan, sikap bahkan perilaku. Prinsip dasar komunikasi adalah proses berkelanjutan (continuing process) dalam proses interaksi dinamis (dynamic interaction) untuk membina hubungan personal, organisasi dan professional.

Komunikasi krisis (crisis communication) adalah proses dialog di antara perusahaan dengan publik, yang dilakukan oleh public relation sebagai bagian dari fungsi manajemen perusahaan. Tujuannya adalah untuk menangani dan menyelesaikan masalah yang terjadi, sebagai bagian dari peran public relation sebagai problem solver.

Strategi dan taktik komunikasi (communication tactic and strategy) yang digunakan oleh perusahaan dalam menangani krisis tersebut, melalui fungsi public relation menggunakan norma dan aturan baku sebagai bagian dari budaya perusahaan, untuk merehabilitasi citra dan reputasi perusahaan pasca krisis.

\section{LITERATUR DAN METODOLOGI}

Etika dijabarkan sebagai pedoman baikburuknya perilaku dalam bentuk nilai-nilai dan azas-azas moral yang digunakan sebagai pedoman umum dalam menentukan baik buruk dan benar-salahnya tindakan manusia sebagai filsafat moral yang menunjukkan bagaimana individu harus bertindak dan melahirkan berbagai istilah etika (ethics, ethic), etis (ethical), moralitas dan moral. Etika merupakan cabang dari ilmu filsafat yang meneliti atas penilaian normative tentang apakah perilaku tertentu benar atau apa yang seharusnya dilakukan. Dan kebutuhan etika berawal dari keinginan untuk mengindari permasalahan-permasalahan dalam dunia nyata (Brooks, 2008:11).

Etika adalah sesuatu yang seringkali dipertukarkan dengan moral dan nilai. Karena pernyataan terkait etika secara umum merujuk pada ada yang baik secara moral atau apa yang seharusnya dinilai. Sedangkan moral merujuk pada tradisi kepercayaan yang telah ada selama kurun waktu lama dalam masyarakat yang menekankan pada apa yang benar dan apa yang salah. Sementara itu, nilai merujuk pada kepercayaan tentang suatu obyek atau ide yang dipandang penting. Karena 
itu, etika dipelajari untuk menentukan penilaian moral dan nilai di dalam kehidupan bermasyarakat (Grunig, 2014:28). Etika juga dipandang sebagai aplikasi dari pengetahuan, pengertian dan penalaran terhadap pertanyaan tentang perilaku benar atau salah dalam praktek professional public relation (Parson, 2008:9).

Dalam Kamus Besar Bahasa Indonesia, etika didefinisikan sebagai a) suatu sistem asas-asas moral; b) tatanan perilaku yang berlaku dalam hubungan dengan suatu kegiatan manusia pada golongan, kelompok maupun kebudayaan tertentu; dan c) cabang filsafat mengenai nilai-nilai dalam kaitannya dengan perilaku manusian tentang kebenaran dan kesalahan dari kegiatan tertentu serta kebaikan dan keburukan dari motif dan tujuan kegiatan tersebut. Sedangkan menurut Oliver (2008:16) etika didefinisikan sebagai a) studi tentang kode-kode etika standar dan penilaian moral; b) risalah tentang moral; dan c) sistem atau kode moral dari filsuf, agama, kelompk profesi tertentu dan lain-lain.

Etika dibedakan dengan kata etik atau etiket, dimana etik berarti kumpulan azas atau nilai yang berkenaan dengan akhlak atau nilai mengenai benar dan salah yang dianut oleh suatu golongan atau masyarakat. Sedangkan etiket berarti tatacara atau adat, sopan santun dalam masyarakat beradab untuk memelihara hubungan baik sesama manusia, yang merupakan persyaratan konvensional sebagai suatu tatacara dalam masyarakat beradab untuk memelihara hubungan baik di antara sesama (Kamus Besar Bahasa Indonesia). Karenanya etiket sangat terkait dengan peradaban (civilization) yang menceminkan keadaan masyarakat yang telah mencapai taraf maju, baik dalam ilmu pengetahuan, industri maupun tatalaksana sosial. Bila etika berkaitan dengan penilaian benar atau salah, dan baik atau buruk yang dilakukan dengan sengaja, etiket lebih merupakan suatu predikat penilaian keberadaban individu dalam kehidupan kesehariannya.

Budaya perusahaan (corporate culture) sebagai seperangkat nilai dan norma yang memandu/ membimbing karyawan, dapat membentuk perilaku etis (ethical behavior) yang akan menimbulkan situasi saling percaya di antara perusahaan dengan stakeholdersnya, yang memungkinkan perusahaan memperoleh keuntungan jangka panjang yang berkelanjutan (long term and sustainable profit). Selain itu, perilaku etis pun akan mencegah tindakan oportunis dari pelanggan, pegawai ataupun pemasok perusahaan.

Untuk menumbuhkan perilaku etis tersebut, perlu dibentuk iklim etika (ethical climate) yang akan terbentuk bila di dalam perusahaan terdapat kesepakatan yang didasarkan kesepahaman luas di antara individu perusahaan tentang perilaku yang dianggap benar serta tersedia mekanisme untuk mengatasi permasalahan etika. Terdapat tiga faktor untuk menciptakan iklim etika di dalam perusahaan yaitu a) terciptanya perusahaan secara baik; b) terbangunnya suatu kondisi organisasi berdasarkan saling percaya (trust-based organization); dan c) terbentuknya manajemen hubungan antar pegawai (employee relationship management) yang baik dan kondusif. Selain itu, iklim etika sangat dipengaruhi oleh interaksi berbagai faktor lainnya yaitu a) kemampuan professional individu dalam menjalankan fungsinya; b) keuntungan perusahaan; c) efisiensi; dan d) kepentingan kelompok.

Kesungguhan perusahaan untuk membangun, memelihara dan mempertahankan etika perusahaan, diformalkan dalam bentuk Kode Etik (code of conduct), yang berfungsi sebagai penyangga (buffer) di dalam interaksi secara intensif di antara beragam ras, pemikiran, pendidikan dan agama. Kode Etik pun dapat dipandang sebagai produk dari etika terapan karena dihasilkan namun hanya mendampingi (dan tidak menggantikan) pemikiran etis. Sehingga dengan adanya Kode Etik tersebut, pemikiran etis tidak berhenti, khususnya dalam iklim keterbukaan dan globalisasi yang memfasilitasi keragaman yang semakin luas.

Peran public relation yang dijabarkan sebagai proses berkelanjutan pihak manajemen perusahaan untuk mensosialisasikan budaya perusahaan termasuk etika dan norma yang wajib di laksananakan dan di patuhi oleh public relation internal dan eksternal perusahaan untuk memperoleh respek dari customer, pegawai dan publik, sebagai kelanjutan dari proses penetapan kebijaksanaan, pelayanan dan sikap yang disesuaikan dengan kepentingan orang atau golongan untuk memperoleh kepercayaan dan jasa baiknya. Sedangkan Roberto Simoes dalam Rumanti (2002:7) mengemukakan karakteristik public relation adalah a) proses interaksi untuk 
menciptakan opini publik; b) sebagai fungsi manajemen; c) aktivitas lintas disiplin ilmu; d) salah satu faktor penting dalam pencapaian tujuan organisasi; dan e) implemenasi kebijaksanaan dan pelaksanaannya melalui interpretasi berbagai peristiwa.

Public relation internal memiliki tujuan utama untuk membuat suasana yang menyenangkan (kondusif) dan keberadaan rasa tanggungjawab yang tinggi pada karyawan perusahaan, public relation external bertujuan untuk mengeratkan hubungan di antara perusahaan dengan para pihak di luar perusahaan. Tujuan yang ingin dicapai oleh publik relation eksternal adalah membentuk opini publik (public opinion) yang baik dan memperoleh pengertian, dukungan dan kepercayaan masyarakat luas.

Sebagai wakil dari manajemen perusahaan, dengan tugas utama menghubungkan pihak yang berkepentingan, baik di dalam maupun di luar perusahaan, public relation harus menguasai etikaetika, baik yang umum maupun tidak umum, berupa a) komunikator yang baik (good communicator), baik untuk publik eksternal maupun internal; b) menempatkan faktor kejujuran (integrity) sebagai landasan utamanya; c) meningkatkan sense of belonging dan sense of wanted pada karyawan; d) menjaga etika dalam komunikasi keseharian dan berinteraksi; e) menyampaikan informasi-informasi penting secara bertanggung jawab, kepada anggota dan kelompok yang berkepentingan; f) menghormati prinsip-prinsip rasa hormat terhadap nilai-nilai kemanusiaan; g) menguasai teknik dan cara penanggulangan kasuskasus, sehingga dapat memberikan keputusan, dan pertimbangan secara bijaksana; $h$ ) mengenal batasbatas yang berdasarkan pada moralitas dalam profesinya; i) penuh dedikasi dalam profesinya; dan j) menaati kode etik humas.

Berkaitan dengan peran sentralnya yang kuat, yaitu sebagai penghubung (di antara perusahaan dengan publik), back-up management dan membentuk corporate image yang baik sehingga seluruh ucapan, sikap dan tindakannya akan menyangkut nilai diri dan citra perusahannya, kualifikasi personal public relation sangat penting. Kualifikasi umum personil public relation adalah a) syarat kepribadian berupa aktif dan kreatif, berpengalaman, sopan, ramah dan simpatik, penuh pengertian, berwawasan luas, berkepribadian kuat dan memiliki referensi yang baik; b) syarat fisik berupa kesehatan yang baik, mudah tersenyum, lancar berbicara, dan suara nyaring/merdu; c) syarat mental berupa bersimpati, teliti dan waspada, bertanggungjawab, serta optimis, jujur dan percaya diri; d) syarat karakter berupa dapat dipercaya, beritikad baik, setia, rajin, teliti, tepat waktu, beritikad baik serta bersikap dan berperilaku terpuji; dan e) syarat sosial berupa pandai bergaul, toleran dan bersedia untuk bekerjasama.

Para professional public relation seringkali dihadapkan pada upaya untuk menanggulangi berbagai permasalahan sebagai individu yang membuat keputusan tentang kehidupan profesionalnya. Selain itu, dituntut pula untuk memberikan pelayanan sebagai konsultan untuk membantu organisasi atau perusahaan agar memiliki cara-cara yang etis, bertanggungjawab dan berorientasi berkelanjutan (sustainable oriented). Dengan demikian etika public relations menekankan pada implikasi-implikasi etis dari berbagai strategi dan taktik yang diterapkan untuk mengatasi masalah yang dihadapinya (Grunnig, 2014:50).

Secara umum, Etika Profesi dinilai sebagai bagian dari etika sosial yang mengatur pelaksanaan tugas, dalam bentuk kualitas dan tanggungjawab penuh sesuai tuntutan pekerjaan, sehingga hasilnya dapat diterima secara baik oleh masyarakat. Pengaturan tersebut dinyatakan dalam bentuk Kode Etik Profesi, yaitu sistem norma, nilai dan aturan professional tertulis, yang dengan secara tegas menyatakan batasan benar-tidak benar dan baiktidak baik serta perbuatan yang harus dilakukan maupun yang dihindari. Dengan demikian, professional diharapkan bersedia dan mampu memberikan jasanya secara optimal terhadap para customernya, sekaligus melindungi para customer tersebut dari kualitas pelayanan yang buruk dan tidak professional.

Terkait dengan pelaksanaan tugasnya, personal public relation harus memiliki etika terkait dengan profesi yang disandangnya (Etika Profesi Public relation), dengan berlandaskan prinsip tanggungjawab, keadilan, otonomi dan integritas moral (Keraf, 2010:19) yang melahirkan kemampuan tertentu berupa a) kemampuan untuk kesadaran etis, yang merupakan landasan kesadaran 
yang utama, bagi individu profesional untuk lebih sensitif dalam memperhatikan kepentingan profesi bukan untuk subjektif, tetapi ditujukan untuk kepentingan yang lebih luas; b) kemampuan untuk berpikir secara etis dan mempertimbangkan tindakan profesi atau mengambil keputusan harus berdasarkan pertimbangan rasional, objektif, dan penuh dengan integritas pribadi serta tanggung jawab yang tinggi; c) kemampuan untuk berperilaku secara etis, yaitu memiliki perilaku, sikap, etika moral dan tata krama yang baik dalam bergaul atau berhubungan dengan pihak lain, termasuk memperhatikan hak-hak pihak lain dan dengan menghormati pendapat atau menghargai martabat orang lain; dand) kemampuan untuk kepemimpinan yang etis (ethical leadership) yakni kemampuan atau memiliki jiwa untuk memimpin secara etis, diperlukan untuk mengayomi, membimbing dan membina pihak lain yang dipimpinnya, termasuk menghargai pendapat dan kritikan dari orang lain demi tercapainya tujuan dan kepentingan bersama

Dalam perspektif internasional, terdapat IPRA Code of Conduct yang merupakan kode etik organisasi public relation international. Ikhtisar dari IPRA Code of Conduct tersebut adalah a) integritas pribadi dan profesional (standar moral yang tinggi), reputasi yang sehat, ketaatan pada konstitusi dan kode IPRA; b) perilaku terhadap klien dan karyawan: i) perlakuan yang adil terhadap klien dan karyawan, ii) tidak mewakili kepentingan yang berselisih bersaing tanpa persetujuan, iii) menjaga kepercayaan klien dan karyawan, iv) tidak menerima fee, dan v) menjaga kompensasi yang tergantung pada pencapaian suatu hasil tertentu; c) perilaku terhadap publik dan media: i) memperhatikan kepentingan umum dan harga diri individu, ii) tidak merusak integritas media komunikasi, iii) tidak menyebarkan secara sengaja informasi yang palsu atau menyesatkan, iv) memberikan gambaran yang dapat dipercaya mengenai organisasi yang dilayani, dan v) tidak menciptakan atau menggunakan pengorganisasian palsu untuk melayani kepentingan khusus atau kepentingan pribadi yang tidak terbuka; dan d) perilaku terhadap teman sejawat: i) tidak melukai secara sengaja reputasi profesional atau praktek anggota lain; ii) tidak berupaya mengganti anggota lain dengan karyawannya atau kliennya; dan iii) bekerjasama dengan anggota lain dalam menjunjung tinggi dan melaksanakan kode etik ini.

Diharapkan dengan mengimplementasikan IPRA Code of Conduct akan terbentuk sikap etis dari personal public relation yang akan berdampak positif pada personifikasi sebagai panutan (role model) maupun citra perusahaan di publik.

Publik (public) merupakan kumpulan orangorang dengan kesamaan minat dan kepentingan terhadap suatu isu, yang dihadapi dan dibincangkan oleh kelompok kepentingan dimaksud, dan akan membentuk opini. Opini merupakan pernyataan tentang sikap sebagai hasil pembicaraan tentang masalah yang berpotensi menimbulkan beragam pendapat. Sedangkan opini publik (public opinion) adalah proses yang menggabungkan pikiranpikiran, perasaan-perasaan, dan usulan- usulan yang dinyatakan oleh publik, yang dikumpulkan melalui diskusi intensif sebagai jawaban atas pernyataan dan permasalahan yang menyangkut kepentingan umum (Arifin, 2011:193).

Opini publik pada dasarnya adalah pendapat rata-rata individu dalam masyarakat sebagai hasil diskusi yang telah disebutkan tadi, untuk memecahkan sebuah persoalan, terutama yang beredar di media massa terkait kepentingan orang banyak. Karenanya, opini publik hanya akan terbentuk jika terdapat isu yang dikembangkan oleh media massa (Arifin, 2011:193). Sedangkan, sikap adalah kecenderungan untuk memberikan respons terhadap suatu masalah atau situasi tertentu. Bila sikap berada dalam diri individu, sedangkan opini (pernyataan atau ekspresi) keluar dari diri individu. Dengan demikian, terdapat suatu keterkaitan yang berkesinambungan di antara opini dan sikap, atau sebaliknya, di dalam diri manusia dalam menghadapi suatu masalah atau situasi tertentu (Tabroni, 2012:85). Pelaksanaan tugas public relation secara cepat, tepat yang dilandasi etika dan perilaku etis yang baik akan sangat menentukan keberhasilan penanganan kondisi krisis, dalam membentuk opini publik positif yang tentunya akan berdampak positif pula bagi citra perusahaan

Penelitian ini bersifat kualitatif dengan mampu membuat gambaran kejadian secara sistematis, faktual dan akurat mengenai fakta, sifat serta hubungan di antara fenomena yang diteliti. Sedangkan metode deskriptif merupakan prosedur pemecahan masalah yang diselidiki 
dengan menggambarkan keadaan subjek atau objek penelitian (individu, komunitas, lembaga masyarakat dan lain-lain) berdasarkan fakta yang tampak atau sebagaimana adanya (Raco, 2017: 56-112).

Sejalan dengan hal tersebut, penulis melakukan proses studi pustaka dengan mengunjungi berbagai pustaka, baik dalam bentuk tulisan maupun virtual (website atau sarana informasi internet), dan mengumpulkan data-data primer melalui bahan-bahan tulisan dalam berbagai bentuk, yang diharapkan dapat memudahkan penulis dalam melakukan penelitian ini.

\section{TEMUAN DAN DISKUSI}

Kasus tumpahan minyak Pertamina di Balikpapan pada 31 Maret 2018, merupakan suatu kejadian fenomenal sebagaimana dikemukakan dalam Tempo.co edisi 17 April 2018 berjudul "DPR Tetapkan Tumpahan Minyak di Balikpapan Kejadian Luar Biasa" sebagaimana disampaikan oleh Ketua Komisi VII Gus Irawan Pasaribu saat rapat kerja dengan PT Pertamina (Persero) ("Pertamina"), Kementerian Lingkungan Hidup dan Kehutanan, Kementerian ESDM serta Kepolisian Daerah Kalimantan Timur tanggal 16 April 2018. Penilaian tersebut dilandasi alasan: a) terdapat lima korban jiwa; b) pencemaran lingkungan hidup seluas 13 ribu hektar; dan c) kebocoran terjadi di obyek vital dengan pengawasan ketat. Sedangkan Kompas.com pada tanggal 10 April 2018, yang diunduh pada tanggal 17 Juni 2018, dalam laporannya berjudul "Tumpahan Minyak di Balikpapan Ditaksir Capai 40.000 Barrel" mengutip penjelasan Direktur Pengolahan Pertamina Toharso bahwa minyak yang tumpah diperkirakan sekitar 40.000 barrel.

Dari sisi public relation, hal yang patut disayangkan adalah lambatnya pihak Pertamina dalam memberikan keterangan resmi dan bahkan pada awalnya membantah bahwa kejadian luar biasa tersebut bukan berasal dari tumpahan minyak miliknya. Opini publik bernuansa negatife kemudian terbentuk setelah diketahui bahwa tumpahan minyak tersebut disebabkan oleh patahnya pipa penyalur minyak mentah dari Terminal Lawe-lawe di Penajam Paser Utara ke kilang Balikpapan. Walaupun selanjutnya, Toharso Direktur Pengolahan PPertamina saat itu mengklaim bahwa Pertamina secara langsung menutup penyaluran minyak mentah dari pipa tersebut, dan mengganti jalur pasokan minyak melalui pipa cadangan dan kapal tanker.

Ternyata, Pertamina tidak mudah mengklarifikasi kebenaran kondisi penyebab kejadian tersebut setelah dari hasil penyelidikan final terbukti bahwa pipa yang dipasang pada tahun 1998 tersebut tersangkut di jangkar kapal MF Ever Judger seberat 12 ton dan tergaruk sejauh 120 meter dari posisi awal hingga akhirnya patah.

Suatu pembelajaran yang berat dan sangat berharga bagi Pertamina, khususnya unit public relationnya dalam menghadapi ketidakpastian dan kekisruhan informasi yang layak disampaikan kepada publik. Bahkan Pertamina dinilai tidak memiliki sistem pengendalian risiko yang terintegrasi (integrated risk management) serta tanggap terhadap kondisi krisis yang ada.

Hal-hal yang dipandang sebagai alasan sehingga Pertamina lambat memberikan tanggapan resmi atas kondisi sebenarnya karena harus mematuhi Etika Profesi Public relation yang melahirkan kemampuan berupa a) kemampuan untuk kesadaran etik yang ditujukan untuk kepentingan masyarakat yang lebih luas berupa ketenangan masyarakat dalam mensikapi potensi timbulnya keresahan dan kegentingan yang luas; b) kemampuan untuk berpikir secara etis dan mempertimbangkan tindakan profesi dimana setiap pernyataan harus dilandasi pertimbangan rasional, objektif, berintegritas dan tanggungjawab, sehingga tidak memberikan pernyataan sebelum memperoleh hasil penelitian secara komprehensif atas kondisi yang sebenarnya terjadi; c) kemampuan untuk bertindak secara etis, yaitu memiliki perilaku, sikap, etika moral dan tata krama yang baik sehingga hanya dapat memberikan pernyataan yang benar-benar terklarifikasi secara jelas dan teruji; dan d) kemampuan untuk kepemimpinan yang demi tercapainya tujuan dan kepentingan bersama, yaitu kepentingan menjaga citra perusahaan yang baik dan terjaga dengan baik.

Namun selanjutnya Pertamina mampu menetralisir keadaan dan mendudukkan permasalahan pada porsi yang sebenarnya sehingga secara bertahap dapat memperbaiki opini publik, khususnya dilandasi oleh tindakan- 
tindakan nyata berupa a) kesungguhan seluruh jajaran perusahaan, khususnya public relation sebagai wakil dari manajemen perusahaan dengan tugas utama menghubungkan para pihak yang berkepentingan, untuk bertindak sebagai komunikator yang baik (good communicator) terhadap publik, baik dalam perspektif eksternal dengan melakukan sosialasi dan eksplanasi yang benar dan transparan atas kondisi yang sebenarnya terjadi dan posisi Pertamina di dalamnya maupun dalam perspektif internal dengan memberikan panduan kepada kalangan internal Pertamina untuk mampu memberikan penjelasan secara baik terhadap masyarakat atas kondisi yang sebenarnya terjadi; b) menjunjung tinggi prinsip kejujuran (integrity) tanpa memanipulasi kondisi yang sebenarnya dalam pendekatan kepada masyarakat terdampak; c) meningkatkan sense of belonging dan sense of wanted pada karyawan sehingga secara bersama-sama memandang dan memperlakukan kondisi krisis sebagai kondisi tak terprediksi (force of majeure) dan harus disikapi dengan sikap keprihatinan dan profesionalisme tinggi; d) menjaga etika dalam komunikasi keseharian dan berinteraksi dengan hanya memberikan informasi resmi dan seragam di seluruh hierarki perusahaan; e) menyampaikan informasi-informasi penting kepada kelompok yang berkepentingan, baik masyarakat terdampak, aparat yang berkenaan maupun LSM dengan sikap keprihatinan atas kondisi krisis; f) menghormati prinsip-prinsip rasa hormat terhadap nilai-nilai kemanusiaan dengan memberikan bantuan berupa tunjangan kehidupan sehari-hari bagi masyarakat terdampak; g) menguasai teknik dan cara penanggulangan krisis secara professional dan bijaksana; h) meengenal batas-batas yang berdasarkan pada moralitas dalam profesinya; i) penuh dedikasi dalam profesinya dengan melaksanakan tindakan yang melebihi tanggungjawabnya semata-mata untuk menanggulangi kondisi krisis yang terjadi; dan $\mathrm{j}$ ) menaati kode etik public relation.

Walaupun tindakan reaktif Pertamina yang tersusun secara sistematis dan holistic tersebut, terbukti mampu merehabilitasi corporate imagenya, untuk selanjutnya Pertamina harus meningkatkan kualifikasi dan sistematika manajemen krisis secara holistic dan terintegratif. Untuk mengimplementasikan manajemen krisis, yaitu proses yang membahas keterkaitan perusahaan dengan suatu perisriwa besar yang mengancam dan berpotensi merugikan perusahaan, stakeholders maupun msyarakat umum, diperlukan peningkatan keterampilan teknis untuk mengidentifikasi, menilai, memahami dan mengatasi situasi yang serius, terutama dari pertama kali terjadi hingga titik pemulihan kembali. Secara esensial, manajemen krisis merupakan upaya untuk menekan faktor ketidakpastian dan faktor risiko serendah mungkin, sehingga akan mampu menampilkan sebanyak mungkin faktor ketidakpastiannya. Hal tersebut perlu didukung oleh informasi mengenai alternatif serta ketidapastian terjadinya kondisi krisis terkait.

Selain itu, Pertamina pun harus melaksanakan tindakan proaktif, khususnya untuk menanggapi opini negatif bahwa Pertamina kurang memiliki risk management yang terintegrasi dan bahkan kurang mampu menghadapi kondisi krisis sejenis (khususnya karena bidang usaha Pertamina sarat dengan risiko yang sangat besar). Tindakan proaktif tersebut antara lain berupa a) manajemen stress (stress management) yang berfungsi sebagai i) simulasi untuk mengelola kondisi terburuk dengan baik sehingga tidak meningkat menjadi tahapan terberat yang tidak mampu dihadapi oleh perusahaan, ii) untuk mampu mengatasi stress yang ada diperlukan suatu tahapan adaptasi, berupa adaptasi teknis, perkembangan, sosial dan budaya; dan iii) pengkondisian dan adaptasi terhadap kondisi terburuk disertai sistematika penanganan yang tepat akan meningkatkan kesiapan perusahaan menghadapi kondisi terburuk yang berpotensi terjadi; dan b) analisa sensitivitas (sensitivity analysis) yaitu suatu pengujian terhadap suatu kondisi dengan menggunakan berbagai asumsi dasar yang berkenaan sepeeti peningkatan biaya produksi, penurunan harga jual; dan c) analisa prediksi (predictive analysis) yaitu analisa yang mengesktraksi informasi berdasarkan data yang terjadi sebelumnya untuk menentukan pola dan memprediksi outcome dan trend yang akan terjadi dalam memahami kebutuhan konsumen, sehingga menentukan skenario what-if dan penilaian risiko (risk assessment).

Untuk mengoptimalkan peran dari strategi akselerasi pengelolaan perusahaan tersebut, perlu 
disertai dengan perbaikan paradigma, kompetensi dan kesiapan untuk menghadapi kondisi krisis terburuk yang berpotensi dihadapi oleh perusahaan selanjutnya. Adalah suatu hal yang bijak untuk senantiasa memandang kondisi krisis dan strategi penanganannya sebagai pembelajaran yang bermanfaat dan kesempatan untuk meningkatkan kesiapan perusahaan menghadapi kondisi krisis di masa mendatang.

\section{SIMPULAN}

Dalam menunjang peran sentralnya sebagai penghubung di antara perusahaan dengan publik, baik dalam perspektif internal untuk membangun suasana kerja kondusif dengan tingginya kepedulian, kesadaran dan rasa memiliki di antara karyawan, maupun dalam perspektif eksternal untuk membangun hubungan perusahaan dengan publik dan citra perusahaan yang baik, diperlukan kualifikasi personil public relation yang tinggi. Selain memenuhi kualifikasi umum berupa syarat keptibadian, syarat fisik, syarat mental, syarat karakter dan syarat sosial, diperlukan sikap dan perilaku etis yang tinggi, baik untuk membentuk personifikasi panutan (role model) maupun perusahaan.

Kesungguhan personil public relation dalam menjalankan peran sentralnya tersebut, sangat diperlukan dalam menangani kondisi krisis yang diklasifikasikan sebagai force majeure, baik untuk membentuk opini publik positif maupun merehabilitasi opini publik negatif yang telah terlanjur terbentuk. Namun disamping tindakan reaktif, untuk selanjutnya perusahaan perlu melaksanakan strategi proaktif untuk mengantisipasi potensi krisis yang mungkin terjadi di masa depan, dalam bentuk stress management, sensitivity analysis dan predictive analysis yang pada dasarnya merupakan suatu simulasi kondisi terburuk dan kesiapan perusahaan menghadapinya.
Tentunya dengan tidak meninggalkan prinsip penanganan pembentukan opini publik positif melalui perilaku etis dari seluruh jajaran perusahaan, terutama public relation.

\section{DAFTAR PUSTAKA}

Arifin, Anwar. 2011. Komunikasi Politik: Filsafat, Paradigma, Teori, Tujuan, Strategi, dan Komunikasi Politik Indonesia. Yogyakarta: Graha Ilmu.

Badan Pengembangan dan Pembinaan Bahasa. (2016). Kamus Besar Bahasa Indonesia. Jakarta: Balai Pustaka

Brooks, Leonard J. 20078. Etika Bisnis dan Profesi, Edisi 5. Penerbit Salemba Empat

Grunig, E. James. 2014. Excellence in Public Relations and Communication Management. Lawrence Earlbaum Associate, Inc. USA

Parson, Patricia J. (2008). Ethics in Public relation: A Guide to Best Practice. EAN: 9780749477264

Raco, J.R. (2017). Metode Penelitian Kualitatif. Jakarta: Grasindo.

Oliver, Sandra M. (2008) Handbook of Corporate Communication and Public relations Pure and Applied

Tabroni, Roni. (2012). Komunikasi Politik Pada Era Multimedia. Bandung: Simbiosa Rekatama Media.

https://nasional.tempo.co/read/1080196/dprtetapkan-tumpahan-minyak-di-balikpapankejadian-luar-biasa

h t t p s : // e k o n o m i.k o m pas . c o m / $\mathrm{read} / 2018 / 04 / 10 / 170400426 /$ tumpahanminyak-di-balikpapan-ditaksir-capai40.000-barrel 